\title{
The Research on the Current Logistics Situation and the Dry Port Development of Mongolia
}

\author{
$O$ dir $M$ yagmarsuren ${ }^{1}$ ( $M$ ongolia), $M$ inrong $D$ eng $^{2}$ (C hina)
}

\begin{abstract}
$\mathrm{N}$ owadays, Mongolia has continually expanded the range of its foreign trade cooperation to include an increasing number of trade partners, which constructed its characteristic mercantile cooperative system, including the two significant neighboring countries, China and Russia, as its strategic partners, the Northeast Asia, as its major imports-exports area, and the increasingly enhanced trade cooperation with the Western countries. Mineral substance is one of the most important exports of Mongolia, which has created considerable foreign exchange receipt. However, as a land-locked country, Mongolia still faces the problems like weak logistics system and backward infrastructure, which impede the further development of the international trade of Mongolia. Building dry ports could shorten the distance between the inland areas and the international markets.
\end{abstract}

Keywords: Dry port, Logistic, Supply Chain Performance

\section{Introduction}

Mongolia has established foreign trade relationship with 132 countries, and has exported products to 68 counties, like China, Russia, Britain, America, and Canada, etc., which created the total trade volume for 9.3853 billion dollars in 2013[1]. High-tech imports and low-tech exports is one of the most distinctive characteristics of Mongolian foreign trade structure. According to the World Bank Annual Report 2014, the LPI (Logistics Performance Index) of Mongolia was 2.36 , which ranked the 135 th among the 160 countries in the world[2]. The lack of direct coastal port is one of the restraints for the economic development of the land-locked countries. In addition, the backward infrastructure is also one of

\footnotetext{
1 Zhejiang University, School of Management, 866 Yuhangtang Road, 310058 Hangzhou, Zhejiang Province, China

2 Ochir Myagmarsuren, Deng Mingrong diamond_ochir@yahoo.com , dengmr@zju.edu.cn
} 
the biggest restraints which greatly decrease the competitive power of Mongolia in international environment.

Dry port refers to the extending of the function of ports to the cities which are lack of coastal port[3], in other words, it means the logistics centers built in the inland regions, authorizing the port service functions, such as customs clearance, inspection, and issuing bills of landing, etc. The Economic and Social Commission for Asia and the Pacific (ESCAP) proposed the following working definition of dry ports during a regional meeting of dry ports in Asia[4]."A dry port provides services for the handling and temporary storage of containers, and general and/or bulk cargoes that enter or leave the dry port by any mode of transport, including roads, railways, inland waterways or airports. Full customs-related services and other related services, such as essential inspections for cargo export and import, should be put in place in a dry port whenever possible. Some of the supervisory organizations such as customs and quarantine institutions are established in the dry ports, in order to provide clearance service to the customers. Otherwise, the affiliated agencies of forwarder shipping agents, shipping agencies, ship-owning companies are also established in the dry ports, in order to enable the local trade activities like delivery, redelivery, and combined transport bill of lading issuing, regarding the locality as the shipment or terminal port. The inland importers and exporters could complete the formalities like space chartering, customs clearance, and inspection locally, and transmit the products to the forwarding or shipping companies. Except the lack of the functions of port loading and unloading, dry port has no distinction from port. Dry port could not only decrease the logistics cost of supply chain, but also enhance the competitiveness of the enterprises[5].

We analyze the current logistics situation in Mongolia, and explore possibility and significance of constructing dry ports there.

\section{The Current Situation of Import-Export Trade and Logistics in Mongolia}

\subsection{The Current Situation of Import-Export Trade}

In 2013, the amount of exports of Mongolia was 5.696 billion dollars. Mongolia has been exporting products to 68 countries, including China for $89 \%$ of amount, Russia for $2.7 \%$, Britain for $2.3 \%$, America for $0.2 \%$, and Canada for $4.1 \%$, and the sum export amount to these countries takes $94.5 \%$ of the total amount. Among the amount of exports, minerals account for $40 \%$, light industrial products for $25 \%$, and animal by-products and other raw material for $35 \%$. The development of Mongolia's export economy relies on China, Russia, and Canada greatly, especially China. Now, the number of Mongolia's trade partners has grown to over 70, mainly including the Asian economic giants and newly industrialized 
countries, like China, Japan, Korea, and Singapore, and the Western developed countries, like America, Germany, Britain, and Switzerland. Over all, Mongolia has continually expanded the range of its foreign trade cooperation and the scope of its partnership, which constructed its characteristic mercantile cooperative system, including the two significant neighboring countries, China and Russia, as its strategic partners, the Northeast Asia, as its major imports-exports area, and the increasingly enhanced trade cooperation with the Western countries.

High-tech imports and low-tech exports is one of the most distinctive characteristics of Mongolian foreign trade structure. For recent 50 years, the high-tech industrial products such as mechanical equipment's have been the main imports, while the raw materials and the raw products have been the main exports of Mongolia's foreign trade. According to the statistical result, about 70 000 kinds of products are imported into Mongolia yearly. Among the amount of imports, mechanical equipment's and transport machinery account for about $41 \%$, metalwork, minerals, and fuels for $28 \%$, and daily living equipment's and foodstuff for about $22 \%$. While for the amount of exports, minerals account for $40 \%$, animal by-products and other raw material for $35 \%$, and light industrial products for $25 \%$ [6].

\subsection{The Current Situation of Logistics}

The majority logistics quantity in Mongolia is undertaken by the rail and road transportation. Currently, there is only one railroad line in Mongolia, which is used to transport resources like coals, copper, and crude oil, etc[7]. As the large amount of the exports has gone beyond the transportation capacity of the Mongolian railway system, the road system has to accommodate that amount of transportation, which would increase the transportation cost. The Mongolian current railroad line is 1815 kilometers in length, linking its capital with every mineral occurrence and China and Russia. The rail way linking with China and Russia is 1110 kilometers in length, and there is rail way in the east linking with Siberia, Russia. For the past ten years, the transportation amount of Mongolia has been doubled, and the basic transportation capacity for one rail way is 20 trains each day. Because the difference of the track gauges in China and Mongolia, the products should be reloaded to another train while passing through the territory, which not only delays the transportation time, but also increases the transportation cost. On the other hand, the majority of the products via road transportation of Mongolia are coals, minerals, and other imports and exports. Currently, the majority of the coals exploited from the south have been exported to China via road transportation. The road system is 200 thousand kilometers in length totally, but only 1250 kilometers of which is covered by hard surface, and most of the rest is covered by sand-gravel surface or uneven surface. 
According to the World Bank Annual Report 2014, the LPI (Logistics Performance Index) of Mongolia was 2.36[8], which ranked the 135th among the 160 countries in the world. The lack of direct coastal port is one of the restraints for the economic development of the land-locked countries like Mongolia.

\begin{tabular}{|c|c|c|c|c|c|c|c|c|c|}
\hline Country & Year & $\begin{array}{l}\text { LPI } \\
\text { Rank }\end{array}$ & LPI Score & $\begin{array}{c}\text { Customs } \\
?\end{array}$ & $\begin{array}{c}\text { Infrastructure } \\
?\end{array}$ & $\begin{array}{c}\text { International } \\
\text { shipments } \\
?\end{array}$ & $\begin{array}{c}\text { Logistics } \\
\text { competence } \\
?\end{array}$ & $\begin{array}{c}\text { Tracking \& } \\
\text { tracing } \\
?\end{array}$ & $\begin{array}{c}\text { Timeliness } \\
?\end{array}$ \\
\hline Singapore & 2014 & 5 & 4.00 & 4.01 & 4.28 & 3.70 & 3.97 & 3.90 & 4.25 \\
\hline China & 2014 & 28 & 3.53 & 3.21 & 3.67 & 3.50 & 3.46 & 3.50 & 3.87 \\
\hline Kazakhstan & 2014 & 88 & 2.70 & 2.33 & 2.38 & 2.68 & 2.72 & 2.83 & 3.24 \\
\hline $\begin{array}{l}\text { Russian } \\
\text { Federation }\end{array}$ & 2014 & 90 & 2.69 & 2.20 & 2.59 & 2.64 & 2.74 & 2.85 & 3.14 \\
\hline Botswana & 2014 & 120 & 2.49 & 2.38 & 2.23 & 2.42 & 2.58 & 2.40 & 2.94 \\
\hline Mongolia & 2014 & 135 & 2.36 & 2.20 & 2.29 & 2.62 & 2.33 & 2.13 & 2.51 \\
\hline
\end{tabular}

Table 1

Several countries in East Asia and Central Asia all have to face this kind of situation during foreign trade[9], including Mongolia. For Mongolia, one of the accesses to the sea is toward Russia, and another is toward some coastal ports in the northeast of China. Nowadays, the Mongolian Department of Transportation has been cooperating with the port areas of Russia, in order to enhance their trade activities. However, considering the political factors and economic cost, Mongolia has not placed the main hope of maritime transportation cooperation on Russia, but paid more attention to the cooperation with the port areas in the east of China. As the most vigorous area for economic development, the AsianPacific region could provide Mongolia a direct access to the Pacific Ocean, and introduce more trade and investigation opportunities to Mongolia, which could promote the economic development of Mongolia. Since then, Mongolia has transformed its coal exporting strategy into diversified transportation patterns, based on which, Mongolia has enhanced its cooperation with China. Although the inner economic development of Mongolia grows continually, the government and the economic experts have already realized the limitation of the inner market; therefore, they have begun to think about how to take part in the globalized economic environment.

In 2010, the Mongolian government has announced to formulate the New Railway Development Project [10], which protocolled to develop a railway toward the east from the capital of Umnugovi Aimag(Dalanzadgad), through Dornogovi Aimag(Sainshand), to Dornod Aimag(Choibalsan) is linked with three coastal ports, namely Russian Far East, the estuary of Tumen River, via Arxan in China, and Jinzhou Port, via Zuun Hatavch. 


\section{The Research on the Current Logistics Situation and the Dry Port Development of Mongolia}

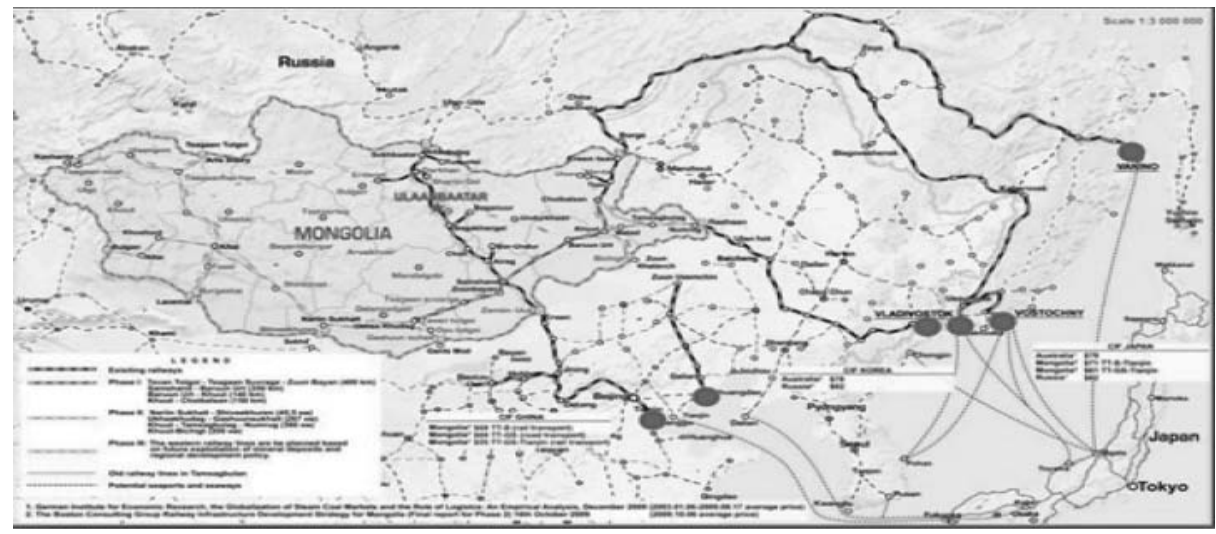

Figure 1. (Mongolia transit corridors and access to seaport)

In the Northern Asia, there are two major road traffic lines linking Asia and Europe, namely Trans-Siberian Railway/ Highway, and New Euro-Asia Railway/ Highway (See Figure 1-2). The former one linked China with Europe, via Russia and Mongolia (the part in Mongolia is oriented north and south, which is 1,110 kilometers in length), while the later one linked China with Europe, via Russia and Kazakhstan.

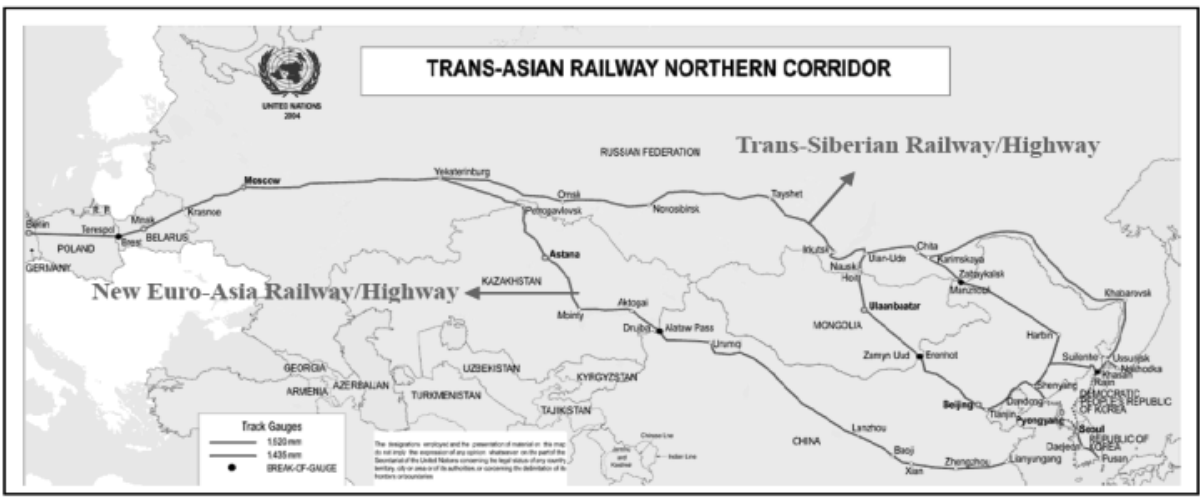

Figure 2. (Trans-Asian railway northern corridor)

Currently, there are five routines of China-Europe Railway/ Highway in operation, but there are only two exits, namely Alataw Pass(Alashankou) in the west and Manchuria in the east, and the Chinese Railway Department has developed the third China-Europe Railway/ Highway in the middle, which links the exit passageway in Erenhot, via the northern part of China. New Euro-Asia Railway/ Highway is a new passageway linking Liaoning, Inner Mongolia, 
Mongolia, and Russia. It is really important, not only for its energy transmission function and proper distributed ports, but also for its potential function to provide more opportunities for the regional economic development. In summary, New Euro-Asia Railway/ Highway is significantly meaningful for the development of Mongolia's port economy and China's export-oriented economy, and the improvement of regional trade cooperation between China and Russia.

\section{Dry port development in China}

China is developing 18 large inland container rail transfer and logistic distribution center [11] as part of its "Go west" strategy to encourage investment in, and the industrialization of, the country's interior. Dry port play an important role in stimulating economic development and facilitating international trade and transport in China's central and western inland areas. In this regard, three aspects of this initiative need careful consideration: (1) the role of the national government in promotion and coordination; (2) the development of dry port infrastructure including other transport infrastructure that links to dry port; and (3) the streamlining of institutional and regulatory frameworks [12]

The Shijiazhuang dry port, with design capacity of 205,000TEU per year, is one of the largest dry ports in China. This dry port has both rail and road access. Customs, inspection, and quarantine are available here. This dry port has direct links with Tianjin seaport and mainly serves as a feeder for that port.

China also has a road-based dry port in Urumqi. A number of small-scale dry port facilities are under construction near the Urumqi railway station. All these dry ports in Urumqi mainly serve markets in Xinjiang and are not used for international trade. International cargo to and from Lianyungang to Alashankou normally bypasses Urumqi.

In terms of cargo volume, Alashankou is the second largest border station in China; it connects to the Dostyk station in Kazakhstan. It can handle all types of cargo; containers, break-bulk, oil, etc. On average, the Alashankou dry port handles about 20 freight trains daily. The Erenhot dry port near the border with Zamyn-Uud in Mongolia also handles containerized and bulk cargo.

Development of dry ports, improvement of railway links and efficiency of double-stack trains mentioned above would improve overall efficiency of the intermodal transport and contribute to overall environmental benefits.

\subsection{Baotou Dry Port}

Baotou Dry Port is the first modern logistics platform operated by Tianjin in the northwest of China in December 2007, combined with land boundary function, port function, and goods distribution function, etc. Based on Baotou International 
Container Freight Station, a work of the International Multimodal Transportation Project aided by the World Bank, as the main body of the construction, Baotou Dry Port also includes 6,600 square meters of customs supervision warehouse, 30,000 square meters of container yard covered by hard surface, railway siding, customhouse, and inspection and quarantine institution. Baotou Dry Port covers 190,000 square meters of land, and was invested for 1.2 billion RMB, which enabled it capable to transport 38,000 standard containers per year. Since Baotou Dry Port began operating, the container transportation volume and income have been increased continually, which strengthened the influence power of Baotou Dry Port in the development of logistics industry and foreign trade in Baotou city. In 2008, Baotou Dry Port has reached the records of 26,386 tons of freight traffic volume, $368,825,211$ ton-km of tonnage mileage, and 36153.1 thousand RMB of operating revenue[13].

The National Regional Development Plan issued by the Chinese State Council has listed Hohhot, Baotou, and Erdos as the key areas of development, and positioned the three cities as the nationally important energy-chemical industry bases, agriculture and livestock products processing bases, rare elements hightech industry bases, and important metallurgy and equipment manufacturing industry bases in the north. The three cities have big economic volume and highlevel of urbanization, and in 2009, the sum of their gross value of production reached 580.499 billion RMB, which account for $59.69 \%$ of the total gross value of the area. Therefore, positioning the three cities in national economic strategy level and offering preferential policies could accelerate the economic integration process of the three cities, which could helpfully solve the problems like industry duplication, vicious competition for investment promotion, and administrative partition, etc., and promote the misplace industry development of the three cities. This kind of adjustment could effectively integrate and distribute the resources of the three cities, and effectively increase the logistics efficiency of Baotou Dry Port.

The development of Baotou Dry Port is still in the initial stage with relatively low influence power, but its function in Baotou logistics industry and foreign trade has been highlighted. Baotou Dry Port has initially realized the seamless joint and inter-extension of Baotou and Tianjin Port, which formed the supply chain from Baotou to Tianjin Port as the exit passageway for the west part of the Inner Mongolia Autonomous Region of China. This supply chain has provided convenient service for the local international trade, and created conditions for Baotou to join Bohai Economic Rim and take part in economic globalization and regional economic integration. Baotou, as the important national basic industrial base, and the biggest industrial city with the largest foreign trade volume of the Inner Mongolia Autonomous Region of China, has exported over $90 \%$ of products 
through Tianjin Port. So, Tianjin Port has always been the traditional port for Baotou's exports. In order to change the Tran-customs transportation form for the local imports and exports, and promote the development of local export-oriented economy, based on the traditional port, the Baotou government has planned to cooperate with Tianjin government to build the Cross Regional Port Project.

\section{Proposal for Dry Port Development in Mongolia}

\subsection{The Basis for Dry Port Development}

With the increasing tendency of the integration of global supply chain, the global industrial distribution is closer to the resource places and the markets. As the significant link of the global supply chain, dry port will be developed as conceptual port in the future, in other words, for the imports and exports trade of the inner land regions, all the port functions would be transferred to the dry port. The only difference between dry port and coastal port is that coastal port has the superior functions as shipment and scale operation, therefore, the dry port distribution will be transferred to the first scenes of production-manufacturing and consumer market, which could not only extend coastal port's function to the inner land, but also minimize the distance between the port and the production site and market, in order to decrease the logistics cost and improve the logistics service quality. According to the logistics integration principle, the added logistics stages could realize the face to face service from the producers and the consumers finally. For instance, the current transfer efficiency and organization of marine hub have been standardized since then, and the negative influence of the intermediate links to the merchants, supply chain organizers, and the logistics operators has been minimized. Therefore, there is no doubt that such a port would be the final pattern of the dry port's development. Dry port development is a systematical engineering, which plays a significant role to promote the inner land region's open economy development, which deeply depends on the basic principle of dry port development, the deep analysis of its demand from view of supply chain, and the combined development of the custom special supervision area, logistics park, and logistics center. Therefore, as one of the most important measures for inner land region's open economy development, the development of dry port should be considered from the perspective of supply chain.

\subsection{Analysis of the Dry Port Development's Demand from Perspective of Supply Chain}

Nowadays, as the well-developed multimodal transport system and information network, the function of dry port should not only be limited as the place of distribution and transshipment, while its ultimate demand is the requirement of 
supply chain, and the distribution and transshipment of the products in dry port is indeed aimed at improving the supply chain's performance, in order to press the supply chain closer to the production sites and markets. Similarly, for the largescale enterprises with multiple supply chains, they should also pay more attention to the demand analysis of the dry port, from the perspectives of the upstream and downstream of the industrial chain.

\subsection{Building Dry Port with Custom Special Supervision Area to Satisfy the Supply Chain's Demand}

Based on the principle of supply chain and development of custom special supervision area, the dry port could satisfy the supply chain's demand more effectively. For instance, through the supply chain, people could press the export rebates to the inner land regions which are closest to the production sites, and press the import bond to the inner land markets which are closest to the consumptions. Therefore, the supply chain's demand is the ultimate demand of dry port.

\subsection{Building Dry Port with Logistics Park (Logistics Center) to Highlight the Large-Scale Net Effect}

For the initial stage of dry port development, solely paying attention to harbor linkage would be a limitation to its growth, because of the limited scale and network, therefore, combining the dry port with the logistics centers (logistics parks) in the supply chain would further satisfy the demand of general logistics and harbor linkage, which could quickly expand the scale of logistics operation and produce network effect, in order to accelerate the development of dry port.

\section{Conclusion and Personal Suggestions}

Mongolia has abundant natural resources, which enables it to have large potential for logistics development. However, the geographical location of Mongolia keeps it a long distance with the international shipping lines, and the development of Mongolian foreign trade transportation is relatively backward, which causes the high logistics cost and restrained development of the Mongolian economy. This situation is widely paid attention to by the relative departments and experts, for instance, Mongolian Parliament has encouraged the development of dry ports in Zamyn-Uud, Altanbulag, UlaanBaatar, Sainshand, and Choibalsan. And I think the development of dry ports in Mongolia should use the experience of the other countries for reference, in case to make detours. And here are my suggestions:

1. Developing a central logistics center, an integrated railway transfer station, and a container transfer station. In Mongolia, even in the capital, 
Ulaanbaatar, is lack of an integrated logistics center. It was generally said by the freight forwarding companies that they need their own equipment for logistics operation. From the view of finance, the current logistics situation of Mongolia has spent too much extra cost which could have been spent on other investment. In addition, the scales of many of the shortage facilities are too small, which need to be expanded and renovated.

2. Developing a scientific management system for the overall planning and comprehensive coordination of the dry port, specifying the rights and obligations of the custom, coastal port, and dry port, simultaneously, enhancing the development of the clearance function and other special functions of dry port, in order to realize the one-time formality complement in the dry port.

3. Developing diversified investment channels. Dry port is a kind of capital concentrated industry with high cost for development. Therefore, we should develop diversified development and investment channels, such as social capital, private capital, and foreign capital, etc., in order to support the scale development of dry port. As long as the investments are beneficial for developing dry port, the government should organize and lead them into operation.

4. Improving the comprehensive quality of the logistics staffs by campus education, on-the-job training, with the combination of basic training and professional training, theoretical training and practical training, in order to develop a group of sophisticated elites in the field of modern logistics management. Besides, we should also introduce a certain amount of logistics advanced talents from foreign countries, in order to build a more positive environment for elite's education.

5. Optimizing each of the service function by optimizing the information infrastructure and IT support system of logistics operation, in order to develop convenient channel system and multimodal transport information system, and fatherly realize the function of export rebates and import bond service of dry port, in order to ensure the stability, convenience, and high-efficiency of the transport channels between dry ports and coastal ports, which is important for the dry port's comprehensive competitiveness.

6. Formulate preferential policies to attract more foreign business and investment, in order to ensure the development of Mongolian dry port and Mongolian export-oriented economy. 


\section{References}

1. Mongolian statistics book 2013 [M].

2. Arvis, Jean-Franzois, et al. "Connecting to Compete 2014: Trade Logistics in the Global Economy--The Logistics Performance Index and Its Indicators." 2014.

3. Zeng, Qingcheng, et al. "Dry Port Development in China." Transportation Journal 52.2 (2013): 234-263.

4. ESCAP, Introduction to the Development of Dry Ports in Asia, 2010.

5. Roso V, Woxenius J, Lumsden K. The dry port concept: connecting container seaports with the hinterland [J]. Journal of Transport Geography, 2009, 17(5): 338-345.

6. Mongolia's Foreign Trade Review Aug 2013

7. National Transport Strategy for Mongolia 2007 ADB

8. lpi.worldbank.org/ 2014-11-022010.

9. Arvis J F, Raballand G, Marteau J F. The cost of being landlocked: logistics, costs, and supply chain reliability [M]. World Bank Publications, 2010.

10. Railway Developments of Mongolia Ministry of Roads and Parliament Resolution No.32, June 24, 2010

11. Wu, J. "The current situation and its development plan of international railway transport corridors in China." ESCAP expert group meeting on operationalization of intermodal transport corridors, Tashkent. 2009.

12. ESCAP, Report of the Regional Expert Group Meeting on the Development of Dry Ports along the Asian Highway and Trans-Asian Railway Networks, Bangkok, 2010.

13. Fan Xiaole. Analysis of the development effect of Tianjin hinterland promoted by dry port— take Baotou dry port for example[J].Modern Business Trade Industry, 2010, 22(23): 108-110 